\title{
Pendampingan Pembuatan Perangkat Pembelajaran Kurikulum 2013
}

\author{
Erna Yayuk $^{1^{*}}$, Santi Prastiyowati ${ }^{2}$ \\ ${ }^{1}$ Pendidikan Guru Sekolah Dasar Fakultas Keguruan dan Ilmu Pendidikan Universitas Muhammadiyah Malang \\ ${ }^{2}$ Pendidikan Bahasa Inggris Fakultas Keguruan dan Ilmu Pendidikan Universitas Muhammadiyah Malang
}

\section{A R T I C L E I N F O}

Article history:

Received 20 August 2019

Received in revised form

10 September 2019

Accepted 30 October 2019

Available online 30

November 2019

\section{Kata Kunci:}

Perangkat pembelajaran

Kurikulum 2013,

penyusunan RPP, guru

Keywords:

Curriculum 2013 learning

tools, arranging Lesson

Plan, teacher

\begin{abstract}
A B S T R A K
Setiap pendidik pada satuan pendidikan berkewajiban menyusun RPP secara lengkap agar pembelajaran berlangsung secara interaktif, inspiratif, menyenangkan, menantang, efisien, memotivasi peserta didik. Kegiatan ini melibatkan kerjasama dengan sekolah mitra. Terdapat satu sekolah yang terlibat dalam kegiatan ini, yaitu SDN Girimoyo 2 Kabupaten Malang. Untuk menyukseskan kemitraan ini, guru yang akan menjadi peserta pelatihan perlu mendapatkan penguatan konsep materi Kurikulum 2013, dan penyusunan RPP. Metode pelaksanaan kegiatan ini yaitu workshop pelatihan, pendampingan dan impelementasi Penyusunan RPP Kurikulum 2013. Pada akhir kegiatan ini, guru akan mengimplementasikan RPP yang telah disusun sesuai kelasnya. Dalam pendesiminasian RPP ini, tim akan mendampingi dan melakukan observasi. Dari Hasil observasi ini yang akan dijadikan bahan Refleksi Bersama. Dapat disimpulkan bahwa guru telah menerapkan Kurikulum 2013 dengan baik. Hal ini dapat diketahui dari RPP yang dirancang dan kegiatan pembelajaran.
\end{abstract}

\section{A B S T R A C T}

Teachers are obliged to arrange their lesson plan to make the teaching and learning process run effectively. It means that an interactive, fun, challenging, efficient teaching and learning process is needed, which, in turn, motivate the learners in their learning process. This program is held in a partner institution, SDN Girimoyo 2 Malang, aiming at giving enrichment in arranging Lesson Plan and its materials based on 2013 Curriculum. A workshop, involving several teachers is conducted to guide the teachers to construct their lesson plan. This program is elaborated into several activities, such as: workshop, guiding activities, and implementation of 2013 Curriculum. In the end of this program, teachers implement their lesson plan based on 2013 Curriculum in their classes. The team guides and observes the class, and the result of the observation will be analyzed. It can be concluded that teachers have implemented the 2013 Curriculum comprehensively, which can be seen from the arrangement of the lesson plan, as well as the teaching and learning process. .

\footnotetext{
* Corresponding author.

E-mail addresses: ernayayuk17@gmail.com (Erna Yayuk)
} 


\section{Pendahuluan}

Kabupaten Malang memiliki Sekolah Dasar (SD) lebih dari lima ratus sekolah, baik negeri maupun swasta. Data Dapodikdasmen (Data Pokok Pendidikan Dasar dan Menegah) Diektorat Jenderal Pendidikan Dasar dan Menegah, menyebutkan bahwa SDN Girimoyo 2 merupakan salah satu sekolah negeri yang berada di Kabupaten Malang. Sekolah yang terletak di Jl. Diponegoro No.37, Girimoyo, Kecamatan Karangploso ini berdiri pada tanggal 17 Januari 2017. Pencapaian status akreditasi sampai tahun ini yaitu B dan kurikulum yang digunakan Kurikulum 2013. Kecamatan Karangploso sendiri berada di Kabupaten Malang Propinsi Jawa Timur. Sekolah ini memiliki luas area sebesar $1657 \mathrm{~km} 2$ dengan jumlah guru sejumlah dua belas orang dan siswa sebanyak 250 orang (130 siswa dan 120 siswi) serta rombongan belajar sebanyak 8 Rombel. Sekolah ini menerapkan Kurikulum 2013 baru pertama kali pada tahun ajaran Genap 2017/2018.

Keduabelas guru di SDN Girimoyo 2, dua diantaranya sudah tersertifikasi sedangkan yang lain statusnya masih guru belum tetap. Dari sisi kualifikasi akademik tidak semuanya berasal dari S1 PGSD. Pada tahun 2017, kegiatan belajar mengajar masih menggunakan Kurikulum 2013. Berdasarkan penelitian Blockgrant yang dilakukan Yayuk, Kuncahyono, dan Restian (2017) terkait kompetensi guru, empat kompetensi guru belum sepenuhnya dikatakan optimal. Hal ini nampak pada kemampuan Pedagogik guru dalam penyusunan RPP belum sepenuhnya memenuhi standar penyusunan RPP, yang diakui beberapa guru terkadang RPP yang dipakai masih mencontoh dari sekolah yang dianggap bagus. Terkait dengan hal ini, penyegaran materi, penyusunan perangkat dalam Kurikulum 2013, update informasi di dunia pendidikan terus harus ditingkatkan.

Pada tahun 2017 dan 2018, PGSD-UMM sudah melakukan pendampingan pembelajaran melalui kegiatan pengabdian internal yang berjudul IbM Pendampingan Digibook (Digital Buku) di SDN Girimoyo 2 Malang dan IbM Pendampingan Penyusunan Perangkat Pembelajaran K13 di SDN Girimoyo 2 Malang. Hasil kegiatan pengabdian menunjukkan peningkatan yang signifikan dalam hal proses pembelajaran. Para guru sudah mampu menggunakan media pembelajaran Digibook (digital Buku) dan penerapan budaya literasi sains. Namun demikian, dalam pembelajaran di kelas belum mampu melaksanakan pembelajaran tematik secara murni. Hasil refleksi diketahui bahwa, kelemahan para guru dalam melaksanakan pembelajaran tematik disebabkan karena Rencana Pelaksanaan Pembelajaran (RPP) yang dibuat masih seperti terkesan menggunakan Kurikulum KTSP, setiap mata pelajaran (Mapel) yang ada belum terintegrasi sepenuhnya. Pada saat melaksanakan pembelajaran tematik, setiap Mapel masih dilakukan per bidang studi. Hal ini belum sejalan dengan Peraturan Menteri Pendidikan dan Kebudayaan No. 67 Tahun 2013 (Biro Hukum dan Organisasi, 2013) yang menyatakan bahwa Kurikulum 2013 untuk sekolah dasar dirancang dengan menerapkan pembelajaran tematik terpadu, yang mulai dilaksanakan dari kelas saru sampai dengan kelas enam.

Lebih lanjut, pembelajaran tematik merupakan model pembelajaran yang menitikberatkan pada pengorganisasian materi yang terintegrasi dan menyatu pada suatu tema (Tirtoni, 2018; Wahyuni, Setyosari, \& Kuswandi, 2016; Yuniasih, Ladamay, \& Wahyuningtyas, 2014). Pembelajaran tematik meliputi beberapa mata pelajaran yang bermakna kepada peserta didik (Jahja \& Septiandini, 2015; Millah \& Syah, 2017; Munasik, 2014; Sulhan, Nurjannah, \& Marlianingsih, 2016; Wahyuni et al., 2016; Warman, 2019). Dalam perkembangannya, pembelajaran tematik dapat membantu siswa dalam memahami suatu konsep secara lebih mudah melalui tema yang dicontohkan dari kehidupan sehari-hari (Saptiani, 2016; Sukayati \& Wulandari, 2009; Sungkono, 2006).

Terkait dengan model pembelajaran, pembelajaran tematik menawarkan beragam model pembelajaran yang membuat kegiatan pembelajaran siswa menjadi lebih relevan dan bermakna, baik secara formal maupun non-formal (Anindya, Suneki, \& Purnamasari, 2019; Ghati, 2018; Ghati \& Respons, 2018; Pembelajaran \& Bagi, 2012; Sirodjuddin \& Surtini, 2012; Wafiqni \& Nurani, 2018). Pembelajaran tersebut melibatkan pembelajaran inkuiri secara aktif sampai dengan penyerapan pengetahuan dan fakta secara pasif melalui pemberdayaan pengetahuan dan pengalaman siswa untuk membantunya mengerti dan memahami dunia kehidupannya. Cara pembelajaran demikian ini akan sangat berpengaruh, dengan melibatkan pengalaman siswa sehingga menjadikan proses pembelajaran lebih efektif dan menarik (Amry \& Badriah, 2018).

Pemenuhan penyusunan perangkat pembelajaran tematik Kurikulum 2013 di sekolah perlu mendapatkan perhatian yang serius (Afandi \& Badarudin, 2011; Indriani, 2015; Priyono, Sulistyorini, Iskandar, \& Mushthafa, 2016). Hal ini disebabkan pada sumber daya manusia di sekolah tersebut dan khususnya pada peserta didik belum siap menghadapi perubahan zaman yang akan datang. Para guru di sana belum memiliki pengetahuan dan keterampilan sepenuhnya untuk memulai menerapkan Kurikulum 2013. 
Berdasarkan permasalahan mitra diatas, maka melalui program IbM tim dosen PGSD mencoba dan mengatasi kendala yang ada, melalui pendampingan langsung terhadap penyusunan perangkat pembelajaran di SDN Girimoyo 2 Malang. Artikel ini bertujuan untuk mendeskripsikan dan menganalisis kegiatan pendampingan pembuatan perangkat pembelajaran Kurikulum 2013 di SDN Girimoyo 2 Malang

\section{Metode}

Metode pelaksanaan IbM ini diawali dengan workshop tentang penyusunan perangkat pembelajaran Kurikulum 2013, khususnya mengenai penyusunan RPP dengan menggunakan pendekatan saintifik beserta penyusunan instrumen evaluasi pembelajaran, Penyusunan LKPD dan bahan ajarnya. Setelah itu dilanjutkan dengan pendampingan terhadap guru dalam menyusun perangkat tersebut dan yang terakhir desiminasi dari RPP yang telah dibuat oleh guru.

\section{Hasil dan pembahasan}

Adapun kegiatan IbM Penyusunan Perangkat Pembelajaran Tematik Kurikulum 2013 di SDN Girimoyo 2 Malang dilakukan melalui kegiatan berikut.

\section{Workshop Penyusunan Perangkat Pembelajaran Tematik}

Kegiatan workshop diikuti oleh guru-guru SDN Girimoyo 2 dengan jumlah dua belas orang guru dan satu kepala sekolah pada 16 Maret 2019. Kegiatan diawali dengan proses sosialisasi program pengabdian. Kemudian dilanjutkan dengan pemberian materi tentang proses penyusunan perangkat pembelajaran tematik Kurikulum 2013. Dokumentasi kegiatan seperti pada Gambar 1.

Guru diminta untuk melakukan analisis buku guru dan buku siswa. Analisis ini diperlukan untuk mengetahui kesesuaian Mapel yang diintegrasikan beserta kesesuaian KI-KD dari setiap Mapel yang diintegrasikan. Pada akhir kegiatan diharapkan peserta mampu membuat satu perangkat pembelajaran (RPP) dengan satu tema dan subtema tertentu yang nantinya akan diimplementasikan di sekolah tersebut.

Guru menghadiri acara workshop yang diawali dengan kegiatan sosialisasi kegiatan pengabdian dan dilanjutkan materi RPP. Adapun materi yang harus dipahami adalah mengenai Pengembangan Bahan Ajar, Penentuan Materi, Penentuan Metode, Model, dan Pendekatan dan Penyusunan RPP dan Silabus. Dengan kegiatan ini, guru akan mampu menentukan RPP yang akan dikembangkan.

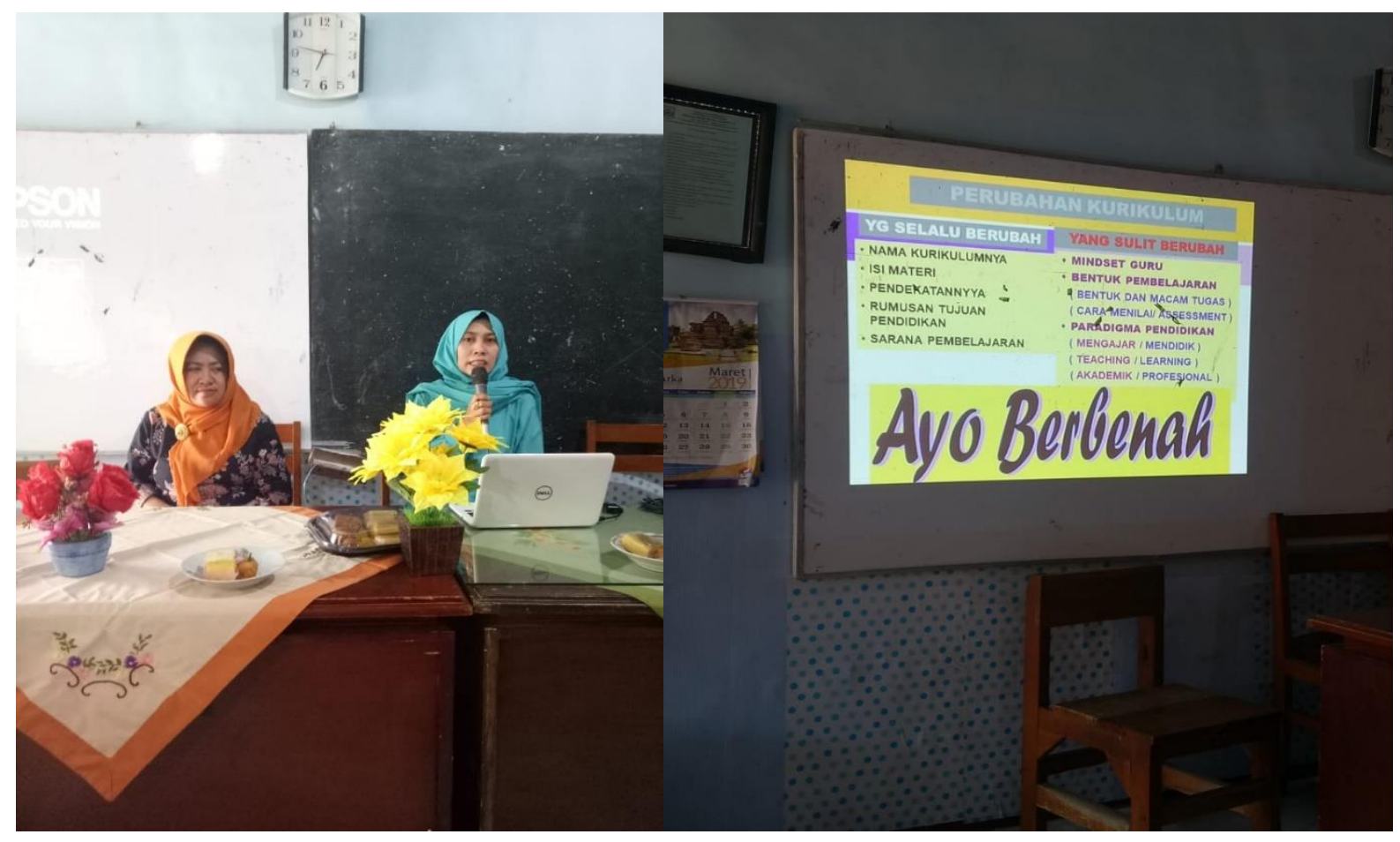

Gambar 1. Tim pengabdian sedang memaparkan materi Kurikulum 2013 


\section{Pendampingan Program Penyusunan Perangkat Pembelajaran Tematik}

Draft rancangan penyusunan RPP yang dihasilkan oleh peserta pelatihan, selanjutnya akan dikembangkan menjadi model RPP di SD tersebut. Selama proses penyusunan, guru-guru mendapat pendampingan secara intensif dari tim pengabdian. Pendampingan juga dilaksanakan sebagai bentuk kolaborasi tim pengabdian dan guru dalam menyusun RPP pembelajaran tematik.

Pada tahap ini, para guru menyusun RPP sesuai dengan rancangan pengembangan yang telah disepakati serta berkolaborsi dengan tim pengabdian dalam rangka penyusunan RPP Kurikulum 2013. Pendampingan dilakukan dengan cara dua kali tatap muka sesuai dengan kebutuhan. Jadwal disesuaikan dengan situasi dan kondisi yang ada di setiap sekolah. Dokumentasi kegiatan seperti pada Gambar 2.

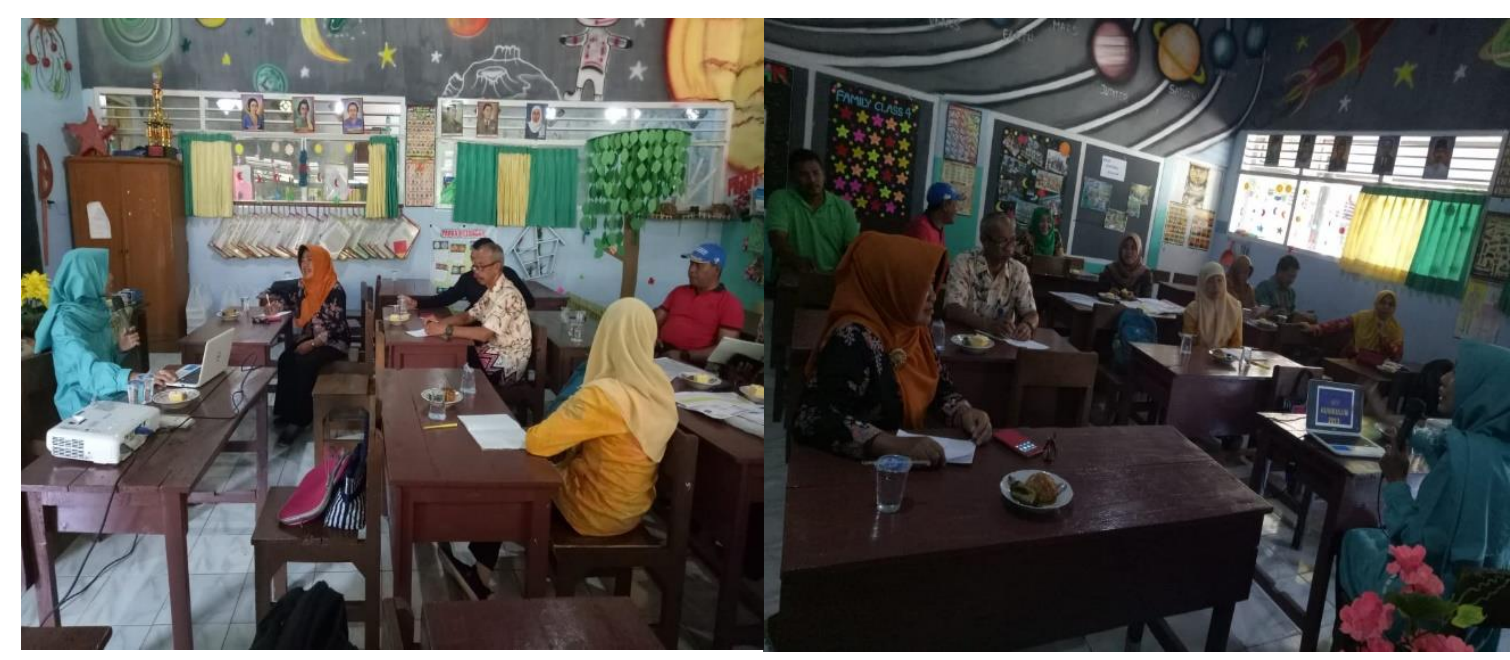

Gambar 2. Kegiatan pemaparan materi

\section{Implementasi Program Penyusunan Perangkat Pembelajaran Tematik}

RPP yang telah dibuat diimplementasikan pada pembelajaran di kelas pada masing-masing bahkan bisa dilakukan secara terpadu. Saat pembelajaran, guru didampingi oleh tim pengabdian. Di akhir pembelajaran, tim pengabdian dan guru mengevaluasi bersama-sama terhadap efektivitas pelaksanaan pembelajaran tematik menggunakan RPP yang telah dikembangkan.

Pada kegiatan ini guru melaksanakan proses pembelajaran dengan menggunakan RPP yang sudah disepakati. Kegiatan pendampingan ini dilaksanakan pada 23 Maret 2019. Para guru menyerahkan RPP yang telah dibuat kepada Tim Pengabdian untuk ditelaah. Dalam kegiatan tersebut, sebanyak dua RPP berhasil disusun., yang kemudian dicermati dan ditelaah untuk diamati apakah kesemuanya telah mencerminkan Kurikulum 2013.

\section{Evaluasi dan Refleksi}

Pada tahap ini dilakukan evaluasi terhadap pelaksanaan pembelajaran tematik yang yang telah diimplementasikan dalam proses pembelajaran di kelas. Selanjutnya, tim pengabdian dan guru akan merefleksi seluruh kegiatan pembelajaran tematik, seperti pada Gambar 3. 


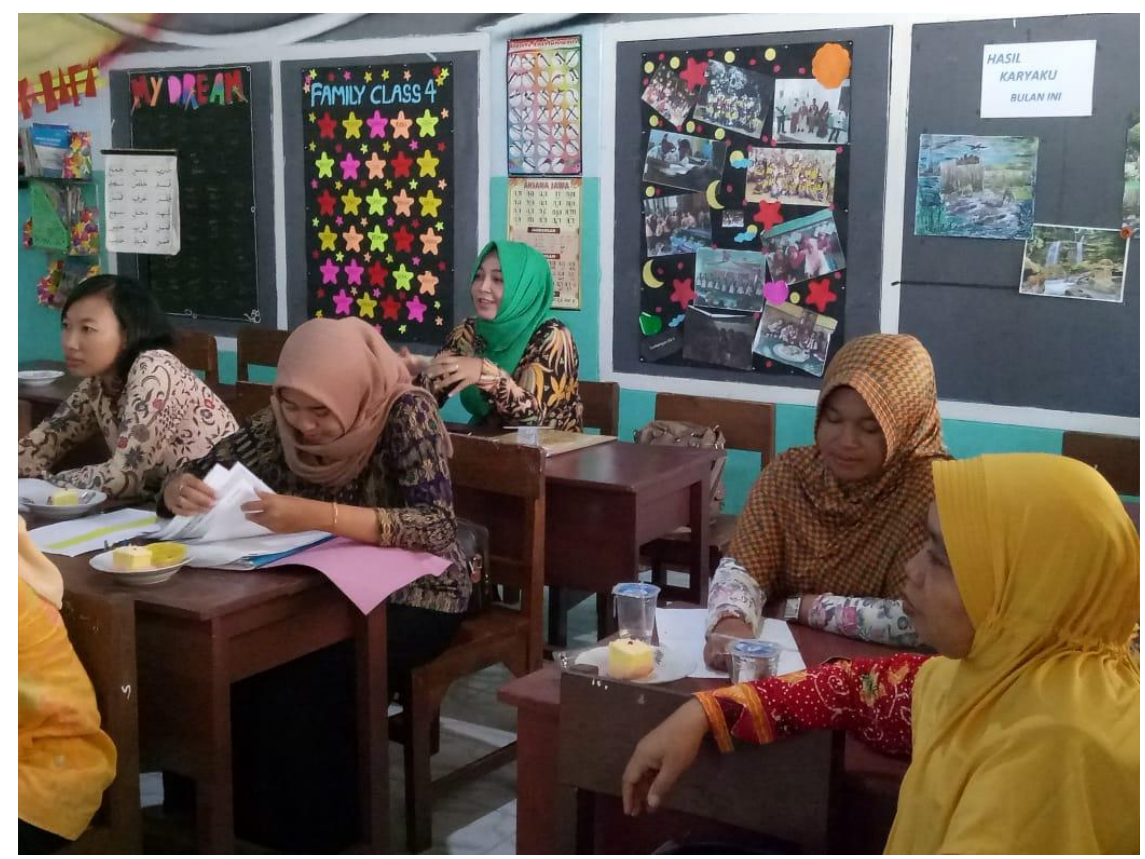

Gambar 3. Kegiatan evaluasi terhadap pelaksanaan pembelajaran tematik

Refleksi dilakukan dengan FGD dengan guru sebagai bahan pertimbangan atau rekomendasi pada kegiatan selanjutnya. Tim pengabdi menganalisa RPP yang telah disusun oleh guru, dalam hal ini RPP untuk kelas IV dan V. Masing- masing akan dijelaskan dalam bagian berikut:

\section{a. RPP kelas IV}

RPP kelas IV mengetengahkan tema "Selalu Berhemat Energi" dan subtheme "Energi Alternatif". Dalam hal ini, guru telah mengimplementasikan garis besar elemen-elemen dalam penyusunan RPP seperti yang telah disampaikan dalam kegiatn workshop. Kompetensi Inti (KI), Kompetensi Dasar (KD) beserta indikatornya, dan tujuan pembelajaran sudah disampaikan dengan jelas. Tahap-tahap pembelajaran sudah dirancang dengan baik dalam langkah-langkah pembelajaran.

Dalam salah satu kegitan pembelajaran, guru mengarahkan siswa untuk praktik membuat layanglayang dalam kelompok (Gambar 4). Kegiatan ini sangat menarik, terbukti dari siswa yang antusias dalam melaksanakan kegiatan ini. Selanjutnya, siswa melaporkan hasil karyanya, mengkomunikasikan kepada teman-teman sekelas dan guru. Kegiatan ini menarik, meskipun sederhana, kegiatan layang-layang masih sangat lekat dengan kehidupan dan merupakan permainan siswa di lingkungan tempat tinggalnya.

Guru sangat memotivasi siswa dalam kegiatan pembelajaran. Dalam hal ini, pemilihan media pembelajaran layang-layang, juga kegiatan proses pembuatannya membangkitkan motivasi dan semangat siswa untuk belajar sesuai dengan topik yang ditentukan. Komunikasi yang baik juga terjalin antara siswa dan guru, juga siswa dengan siswa lainnya.

Guru juga sudah menerapkan system penilaian yang tepat, yaitu menilai kemampuan berbahasa atau berkomunikasi siswa dalam menjelaskan proses pembuatan layang-layang. Selain itu, siswa juga menganalisa dan menghitung energi yang diperlukan untuk bermain layang-layang sebagai aplikasi dari kemampuan saintifik lainnya.

Untuk kegiatan pengayaan, guru belum secara rinci mencantumkan kegiatan di rumah, sebagai penguatan dari materi yang telah disampaikan. Demikian juga untuk rencana remidi bagi siswa yang belum menguasai materi yang telah diberikan. Dapat disimpulkan bahwa dalam pengajaran kelas IV, guru sudah menerapkan RPP yang mengacu pada K13 dengan sangat baik. 


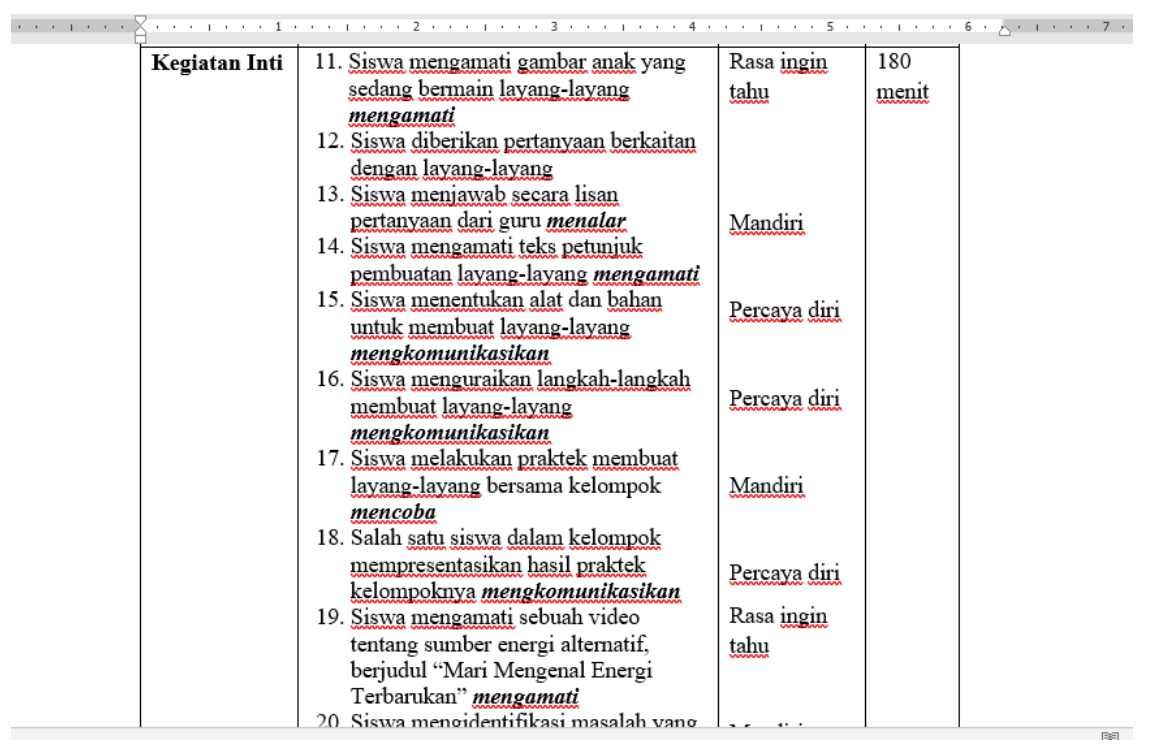

Gambar 4. Kegiatan inti pada RPP kelas IV

\section{b. RPP kelas $V$}

Guru pengajar kelas V mempresentasikan tema "Organ Gerak Manusia dan Hewan", dan "Organ Gerak Hewan" sebagai sub temanya. Secara umum, guru telah memahami penyusunan RPP K13 dan menerapkannya dalam menentukan Kompetensi Inti (KI), Kompetensi Dasar (KD) dan indikatornya, tujuan pembelajaran, dan materi pembelajaran. Guru juga mempertimbangkan pemilihan metode pembelajaran yang sesuai untuk anak didiknya.

Dalam kegiatan pembelajaran, guru mengajak siswa untuk mengamati gambar yang ada dalam buku. Siswa menuangkan hasil pengamatannya dan menuliskannya ke dalam kolom-kolom yang ada dalam buku tugas. Ketepatan jawaban siswa menjadi salah satu aspek penilaian. Selanjutnya, setelah siswa memahami gambar, mereka menceritakan gambar tersebut ke dalam sebuah cerita. Siswa dapat berimajinasi dan berkreasi dengan gambar tersebut. Dalam hal ini guru juga menitikberatkan pada kemampuan siswa dalam berbahasa, khususnya dalam memahami kata hubung, yang disampaikan melalui system gerak vertebrata. Kegiatan inti ini sebagaimana ditunjukkan pada Gambar 5.

Dalam pengajaran topik ini, guru menggunakan buku dan slide sebagai media. Dalam pembelajaran ini, buku siswa berperan sebagai materi utama dan slide mendukung serta memperjelas materi yang terdapat dalam buku. Pada proses pembelajaran, siswa tampak antusias ketika mengamati gambar yang ditampilkan melalui slide, dan juga video yang mendukung proses pembelajaran (Gambar 6). Semangat siswa juga tampak pada proses pembelajaran selanjutnya, misalnya bercerita tentang hewan sesuai dengan imajinasi dan kreativitas mereka.

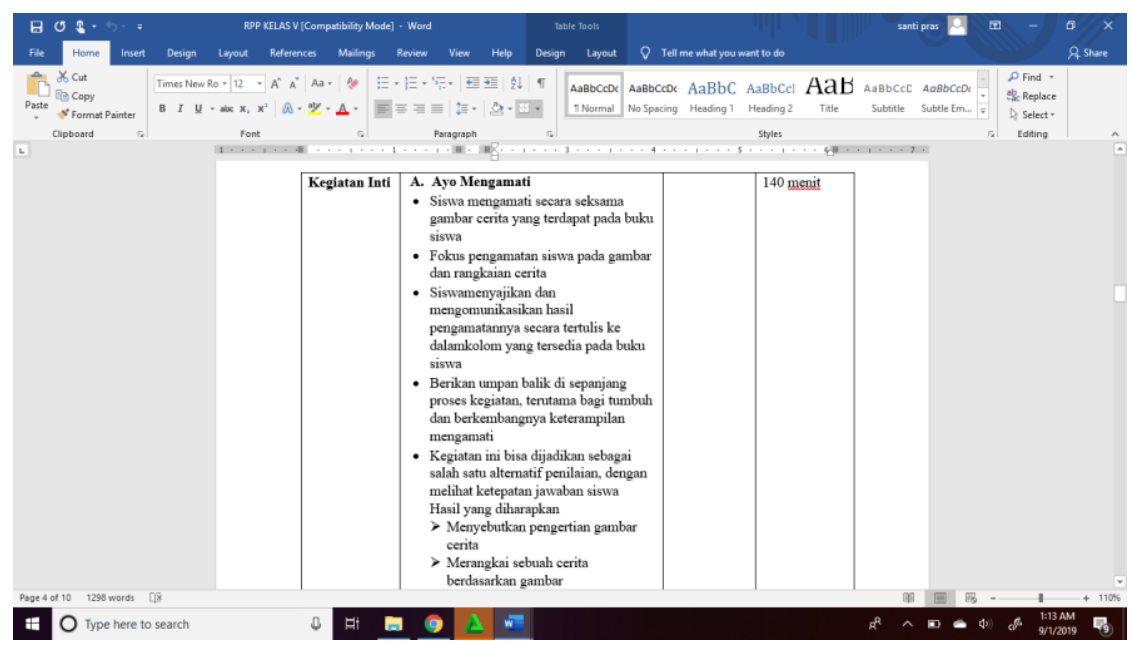

Gambar 5. Kegiatan inti pada RPP kelas V 


\begin{tabular}{|l|l|l|l|l|l|}
\hline No. & Tanggal & $\begin{array}{c}\text { Nama } \\
\text { Siswa }\end{array}$ & $\begin{array}{c}\text { Catatan } \\
\text { Perilaku }\end{array}$ & $\begin{array}{c}\text { Butir } \\
\text { Sikap }\end{array}$ & $\begin{array}{c}\text { Tindak } \\
\text { Lanjut }\end{array}$ \\
\hline 1. & & & & & \\
\hline 2. & & & & & \\
\hline 3. & & & & & \\
\hline 4. & & & & & \\
\hline Dst & & & & & \\
\hline
\end{tabular}

\section{H. REMEDIAL DAN PENGAYAAN}

\section{SUMBER DAN MEDIA}

- Buku bacaan perubahan wujud benda, dan gambar tentang perilaku yang tidak selaras dengan lingkungan.

- Buku pedoman guru tema 1 Kelas 5 dan Buku Siswa Tema 1 Kelas 5 (Buku Tematik Terpadu Kurikulum 2013, Jakarta: Kementeriaan Pendidikan dan Kebudayaan, 2017)

- Video/Slide/Gambar tentang perubahan wujud benda

- Video pelestarian alam dan melindungi dari kerusakan alam

- Kerajinan tradisional wayang golek, seni kerajinan, surat kabar dan majalah

\section{Gambar 6. Sumber dan media pada RPP kelas IV}

Pengajaran tersebut berjalan lancar, namun akan lebih baik lagi bila guru dapat menyediakan media yang lebih menantang kreativitas dan daya berpikir kritis siswa. Suatu misal, guru dapat menyediakan puzzle berbagai hewan vertebarata, dan siswa menyusun serta menjelaskan tentang organ geraknya. Atau, guru dapat mengajak siswa untuk pergi ke luar kelas dan mengamati lingkungan sekitar. Kemungkinan besar hewan vertebrata masih banyak ditemukan di lingkungan belajar siswa.

Selanjutnya, siswa dapat melaporkan pengamatannya terhadap hewan yang ditentukan, menyusunnya dalam cerita atau paragraf, dan ketika kembali ke kelas, mereka bercerita di depan kelas. Dalam hal pengayaan, guru belum merinci secara tepat kegiatan yang diberikan untuk siswa. Demikian juga untuk kegiatan remidi yang diperlukan, belum direncanakan dengan jelas. Untuk menyusun rencana pembelajaran yang sesuai, hal ini seharusnya dicantumkan dengan jelas dalam perencanannya. Meskipun demikian, secara umum, guru sudah menerapkan dan merancang RPP dengan baik.

Kegiatan workshop diikuti guru SDN Girimoyo 2 Karangploso Malang, diawali kegiatan sosialisasi pengabdian. Guru perlu memahami pengembangan bahan ajar, penentuan materi, penentuan metode, model, dan pendekatan dan penyusunan RPP dan Silabus. Sosialisasi kegiatan pengabdian adalah sangat penting untuk mengetahui lebih jelas tentang mitra dan memberikan gambaran Ipteks yang akan ditransfer kepada mitra. Dalam sosialisasi ini tim pengabdian berdiskusi mengenai permasalahan yang harus diselesaikan dalam program pengabdian. Sosialisasi awal ini pun menjadi dasar pelaksaaan tim pengabdian dalam kegiatan selanjutnya (Ady, 2019; Bakung, n.d.; Bisowarno, Novianti, \& Martina, 2017; Hudha, Husamah, \& Hadi, 2011; Husamah, Hudha, \& Pantiwati, 2018; Novita \& Wahyuningsih, 2015; Nurjanah \& Yasir, 2019; Nurwidodo, Rahardjanto, Husamah, \& Mas'odi, 2017, 2018; Sadalia, Hasibuan, \& Sumatri, 2017; Sim, Nelayan, \& Madong, 2018; Suhendar, Ramdhan, \& Sudarma, 2019; Wardhani, 2010; Widowati, Utaminingsih, \& Wahjuningsih, 2018; Wijayanti, Kurniawan, \& Susanto, 2019).

Melalui kegiatan ini guru diharapkan mampu menentukan RPP yang akan dikembangkan. RPP perlu dikembangkan guru dengan menyesuaikan apa yang dinyatakan dalam silabus dengan kondisi di satuan pendidikan (Setiana, 2018; Susanti \& Hamdani, 2017; Syarifuddin, 2018). Dalam hal in yang dimaksud adalah kemampuan awal peserta didik, minat, motivasi belajar, bakat, potensi, kemampuan sosial, emosi, gaya belajar, kebutuhan khusus, kecepatan belajar, latar belakang budaya, norma, nilai, dan/atau lingkungan peserta didik (Suaidi, 2013). Efektivitas pembelajaran tematik dapat dilihat dari kemampuan guru merencanakan dan melaksanakan pembelajaran (Hermawanti, Rasyid, \& Mujtahidin, 2015).

Para guru didampingi secara intensif untuk terus memberikan semangat dan meneguhkan komitmen mereka. Pendampingan juga dilaksanakan sebagai bentuk kolaborasi tim pelaksana pengabdian dan para guru dalam menyusun RPP pembelajaran tematik. Dosa hukumnya bagi guru yang mengajar tanpa persiapan, dan hal tersebut hanya akan merusak mental dan moral peserta didik, serta akan menurunkan wibawa guru secara keseluruhan (Prastyo \& Muhammad, 2015). kemauan belajar guru dari pengalaman dan semangat untuk terus berlatih secara bertahap dan sistematis akan mempertajam kepekaan guru (Zendrato, 2016). Ciri-ciri guru yang mempunyai komitmen tinggi adalah yang mempunyai 
kepedulian,rasa tanggungjawab dan loyalitas terhadap tugas pokok, merasakan dorongan semangat dalam bekerja (Jannah, 2014). Sehubungan dengan itu, untuk pendampingan guru perlu dilakukan oleh dosen. Berdasarkan kenyataan dan kondisi lapangan, dosen harus merasa terpanggil dan memiliki komitmen serta kepedulian untuk meningkatkan kompetensi guru di sekolah mitra (Zuriah, Sunaryo, \& Yusuf, 2016).

RPP yang telah dikembangkan oleh guru, perlu diujicobakan dengan cara mengimplementasikan di di kelas dengan didampingi oleh tim pengabdian. Implementasi pendekatan pembelajaran tematik relatif efektif di sekolah, namun tetap membutuhkan peningkatan sarana-prasarana untuk memfasilitasi proses pembelajaran (Abduh, Nugroho, \& Siskandar, 2014). Implementasi rencana pelaksanaan pembelajaran berbasis kurikulum 2013 dan tematik memerlukan daya dukung sarana prasarana pembelajaran (Purwandari, 2015).

Di akhir pembelajaran, perlu ada evaluasi terhadap efektivitas pelaksanaan pembelajaran tematik. Menurut Rushartatik, Dantes, dan Suandana, (2013) perlu adanya studi evaluasi yang difokuskan pada pelaksanaan pembelajaran tematik. Analisis dilakukan secara keseluruhan terhadap variabel konteks, input proses dan prodruk studi evaluasi pelaksanaan program program pembelajaran tematik. Sedangkan menurut Christie (2015) evaluasi dilakukan untuk mengetahui keberhasilan guru dalam memberikan pembelajaran.

\section{Simpulan dan saran}

Dari kegiatan pendampingan pembuatan perangkat pembelajaran ini dapat disimpulkan bahwa: (1) Kegiatan pelatihan dan pendampingan. Kegiatan secara umum berjalan dengan lancer. Guru mengikuti pelatihan dengan antusias, yang bertujuan untuk meningkatkan wawasan dan kompetensi meraka terkait dengan perangkat pembelajaran berbasis Kurikulum 2013. Guru berhasil menyusun RPP berbasis Kurikulum 2013 dan menerapkannya di kelas masing-masing. (2) Hasil RPP Kurikulum 2013. Dari kegiatan pendampingan ini, guru telah mempraktikkan materi terkait dengan RPP yang telah disampaikan pada waktu pelatihan. Dua RPP yang dihasilkan, yaitu dari Kelas IV dan Kelas V, guru telah menerapkan Kurikulum 2013 dengan baik. Hal ini tercermin dari RPP yang telah dibuat. Meskipun demikian, ada beberapa hal yang perlu ditingkatkan, misalnya dalam hal perincian kegiatan atau aktivitas yang dirancang. Tentu saja hal ini memerlukan waktu, yang tim pengabdi yakini, para guru di SDN Girimoyo 2 Batu belajar dengan cepat dan efektif.

Beberapa saran dapat disampaikan untuk penelitian selanjutnya terkait dengan: (1) Pendampingan dapat dilakukan secara lebih intensif untuk memfalisitasi guru dalam menyusun RPP yang diharapkan, sesuai dengan Kurikulum 2013. Diperlukan juga waktu diskusi yang lebih Panjang untuk menganalisa dan melakukan pembenahan/ revisi atas RPP yang telah dirancang. (2) Untuk memperkaya wawasan guru mengenai ragam media pembelajaran, diperlukan pula waktu tersendiri untuk memberikan pelatihan bagi guru dalam membuat atau merancang media pembelajaran yang menarik bagi siswa

\section{Daftar Rujukan}

Abduh, M., Nugroho, N., \& Siskandar, S. (2014). Evaluasi pembelajaran tematik dilihat dari hasil belajar siswa. Indonesian Journal of Curriculum and Educational Technology Studies, 1(1), 1-9.

Ady, S. U. (2019). Mengubah paradigma saving society menjadi investment society (peran serta wanita dalam meningkatkan ekonomi keluarga melalui investasi di Bursa Efek Indonesia): Laporan akhir pengabdian pada masyarakat. Surabaya.

Afandi, M., \& Badarudin, B. (2011). Perencanaan Pembelajaran di Sekolah: Dengan Memasukkan Pendidikan Budaya dan Karakter Bangsa. Bandung: Penerbit Alfabeta.

Amry, Z., \& Badriah, L. (2018). Pembelajaran tematik sebagai upaya meningkatkan keaktifan peserta didik. ELEMENTARY: Islamic Teacher Journal, 6(2), 254-270. https://doi.org/10.21043/elementary.v6i2.4388

Anindya, E. F. Y., Suneki, S., \& Purnamasari, V. (2019). Analisis Gerakan Literasi Sekolah Pada Pembelajaran Tematik. Jurnal Ilmiah Sekolah Dasar, 3(2), 238-245.

Bakung, D. (n.d.). Pemberdayaan ibu-ibu PKK dalam pemanfaatan jamu tradisional untuk mengatasi fatigue \& myalgia di Ngering, Desa Bakung, Jogonalan, Klaten. 
Biro Hukum dan Organisasi. Peraturan Menteri Pendidikan dan Kebudayaan Nomor 67 Tahun 2013 Tentang Kerangka Dasar dan Struktur Kurikulum Sekolah Dasar/Madrasah Ibtidaiyah (2013).

Bisowarno, B. H., Novianti, J., \& Martina, A. (2017). Penerapan teknologi tepat guna dalam penyediaan air bersih di sekolah dan peningkatan ekonomi masyarakat di Desa Cukanggenteng. Bandung.

Christie, 0. (2015). Keefektifan pendekatan pembelajaran tematik terpadu di sekolah dasar. Indonesian Journal of Curriculum and Educational Technology Studies, 3(1), 31-40.

Ghati, E. W. (2018). Dengan Model Pembelajaran Berbasis Masalah Berdasarkan Taksonomi Solo. Jurnal Pedagogik, 5(2), 209-216.

Ghati, E. W., \& Respons, S. (2018). Dengan Model Pembelajaran Berbasis Masalah Berdasarkan Taksonomi Solo, 05(02), 209-216.

Hermawanti, A. S., Rasyid, H. Al, \& Mujtahidin, M. (2015). Efektivitas pembelajaran tematik ditinjau dari kemampuan guru merencanakan dan melaksanakan pembelajaran di kelas V SD Muhammadiyah 8 Kecamatan Tulangan tahun 2015. Widyagogik, 3(1), 79-89.

Hudha, A. M., Husamah, H., \& Hadi, S. (2011). Pendampingan pengembangan perangkat pembelajaran laboratorium untuk menunjang pelaksanaan bagi guru IPA biologi SMP Muhammadiyah 1 Malang. Jurnal Dedikasi, 8(1), 43-51.

Husamah, H., Hudha, A. M., \& Pantiwati, Y. (2018). Pendampingan guru SMPN 8 Kota Malang dalam mengembangkan perilaku etis siswa berbasis model pembelajaran OIDDE. International Journal of Community Service Learning, 2(2), 41-50. https://doi.org/10.23887/ijcsl.v2i2.14185

Indriani, F. (2015). Kompetensi Pedagogik Mahasiswa Dalam Mengelola Pembelajaran Tematik Integratif Kurikulum 2013 Pada. Junal Profesi Pendidikan Dasar, 2(2), 87-94.

Jahja, R. S., \& Septiandini, D. (2015). Praktik Pembelajaran Tematik di Sekolah Dasar Dengan Pendekatan Sosiologi. Indonesian Journal of Sociology and Education Policy, 2(1), 1-23. Retrieved from http://download.garuda.ristekdikti.go.id/article.php?article=809920\&val=13228\&title=Praktik Pembelajaran Tematik di Sekolah Dasar Dengan Pendekatan Sosiologi

Jannah, W. (2014). Komitmen Guru dalam Melaksanakan Tugas di Sekolah Menengah Atas (SMSA) Kecamatan Rokan IV Koto. Bahana Manajemen Pendidikan, 2(1), 789-796.

Millah, D., \& Syah, M. N. S. (2017). Implementasi pembelajaran tematik integratif di kelas I Sekolah Dasar Negeri 2 Barongan Kudus. Elementary, 5(2), 251-278.

Munasik, M. (2014). Kemampuan guru sekolah dasar dalam menerapkan pembelajaran tematik di sekolah. Jurnal Pendidikan, 15(2), 105-113.

Novita, E., \& Wahyuningsih, W. (2015). IbM pemanfaat limbah cair proses pengolahan buah kopi sebagai sumber energi alternatif pada proses pengolahan kopi dan keperluan rumah tangga. Jember.

Nurjanah, N., \& Yasir, Y. (2019). Komunikasi pariwisata dalam pengembangan pemberdayaan masyarakat desa wisata di Kecamatan Bantan. In Prosiding Seminar Penelitian dan Pengabdian (pp. 359-370). Pekanbaru: $\quad$ FISIP Universitas Riau. Retrieved http://repository.unri.ac.id/handle/123456789/9636

Nurwidodo, N., Rahardjanto, A., Husamah, H., \& Mas'odi, M. (2017). Pendampingan pembuatan aneka olahan rumput laut sebagai upaya penguatan ekonomi masyarakat Kepulauan Sapeken Sumenep. Senaspro 2, 700-714.

Nurwidodo, N., Rahardjanto, A., Husamah, H., \& Mas'odi, M. (2018). Pendampingan masyarakat dalam budidaya rumput laut di Kepulauan Sapeken Kabupaten Sumenep Jawa Timur. International Journal of Community Service Learning, 2(3), 157-166. https://doi.org/10.23887/ijcsl.v2i3.14770 
Pembelajaran, P., \& Bagi, T. (2012). Pelaksanaan Pembelajaran Tematik Bagi Anak Tunagrahita. EJUPEKhu (JURNAL ILMIAH PENDIDIKAN KHUSUS), 1(3), 305-319.

Prastyo, Z., \& Muhammad, H. N. (2015). Analisis Kemampuan Guru dalam Pembuatan RPP Kurikulum 2013 dan Pembelajaran Pendidikan Jasmani Kesehatan dan Olahraga (PJOK) Se-Kecamatan Gununganyar Kota Surabaya. Jurnal Pendidikan Olahraga Dan Kesehatan, 3(2), 492-500.

Priyono, S., Sulistyorini, S., Iskandar, D., \& Mushthafa, M. (2016). Modul Kepala Sekolah Pembelajar Kelompok Kompetensi 06: Pengelolaan Kurikulum. (H. Hasan, H. Widyaistono, M. Mariati, \& M. Y. Saad, Eds.). Jakarta: Direktorat Jenderal Guru dan Tenaga Kependidikan.

Purwandari, E. L. (2015). Implementasi rencana pelaksanaan pembelajaran berbasis kurikulum 2013 pada mata pelajaran ekonomi di SMA Negeri 2 Sukoharjo. Fakultas Keguruan dan Ilmu Pendidikan, Universitas Muhammadiyah Surakarta.

Rushartatik, R., Dantes, N., \& Suandana, G. A. (2013). Studi evaluatif pembelajaran tematik di kelas permulaaan se- kecamatan kuta utara badung. E-Journal Program Pascasarjana Universitas Pendidikan Ganesha, 4, 1-10.

Sadalia, I., Hasibuan, B. K., \& Sumatri, I. B. (2017). Pendampingan dan peningkatan kapasitas dan kualitas produksi jamu yang berbasis green system. Abdimas Talenta, 2(1), 6-11. Retrieved from https://jurnal.usu.ac.id/index.php/abdimas/article/view/18276

Saptiani, S. (2016). Model pembelajaran tematik anak usia dini dalam kurikulum 2013. JEA, 1(1), 14-35.

Setiana, D. S. (2018). Meningkatkan kemampuan menyusun RPP dengan pendekatan saintifik mahasiswa pendidikan matematika universitas sarjanawiyata tamansiswa yogyakarta. In Prosiding Seminar Nasional MIPA 2018 (pp. 120-131). Magelang.

Sim, M., Nelayan, K., \& Madong, D. (2018). Pendampingan dalam operasionalisasi sistem informasi manajemen (SIM) kelompok nelayan Desa Madong. Journal of Maritime Empowerment, 1(1), 6-10.

Sirodjuddin, K., \& Surtini, N. (2012). Studi Efektivitas Pembelajaran PAUD Berbasis Tematik Sebuah Studi Kasus di PAUD Seatap Margaluyu Kecamatan Cipatat Kabupaten Bandung Barat. Jurnal EMPOWERMENT, 1(2), 105-120.

Suaidi, S. (2013). Penyusunan Rencana Pelaksanaan Pembelajaran (Implementasi Kurikulum 2013) | Suaidinmath'S Blog. $\quad$ Retrieved October 30, 2019, from https://suaidinmath.wordpress.com/2013/12/29/penyusunan-rencana-pelaksanaanpembelajaran-implementasi-kurikulum-2013/

Suhendar, S., Ramdhan, B., \& Sudarma, A. (2019). Program penerapan teknologi tepat guna implementasi ASTER (Alat silase terkompartemen) untuk peternak domba di Wilayah Kadudampit Kabupaten Sukabumi. Sarwahita, 15(01), 32-40. https://doi.org/10.21009/sarwahita.151.04

Sukayati, S., \& Wulandari, S. (2009). Pembelajaran tematik di SD: Modul Matematika SD Program BERMUTU. (A. Waluyati, Ed.). Sleman: Pusat Pengembangan dan Pemberdayaan Pendidik dan Tenaga Kependidikan (PPPPTK) Matematika.

Sulhan, M., Nurjannah, N., \& Marlianingsih, N. (2016). Penggunaan strategi pembelajaran tematik dalam pembelajaran bahasa inggris pada Yayasan Pendidikan Dan Sosial Daarul Kirom. Faktor Jurnal Ilmiah Kependidikan, 3(1), 59-64.

Sungkono, S. (2006). Pembelajaran Tematik Dan Implementasinya Di Sekolah Dasar. Majalah Ilmiah Pembelajaran, 2(1), 51-58.

Susanti, N. E., \& Hamdani, A. F. (2017). Pelatihan penyusunan rencana pelaksanaan pembelajaran (RPP) Kurikulum 2013 di SDN Kedok 01 Turen Kabupaten Malang. In Seminar Nasional Hasil Pengabdian kepada Masyarakat 2017 PELATIHAN (pp. 307-313). Retrieved from 
https://semnas.unikama.ac.id/lppm/prosiding/2017/Pengabdian/45.Raymond_Nanik_Pengabdian _Ekonomi_dan_bisnis.pdf

Syarifuddin, K. (2018). Inovasi Baru Kurikulum 2013 Pendidikan Agama Islam dan Budi Pekerti,. Sleman: Deepublish. Retrieved from https://books.google.co.id/books?id=xYVJDwAAQBAJ\&pg=PA89\&dq=pengertian+rpp\&hl=id\&sa=X \&ved=0ahUKEwip2o3M5ojlAhVFVH0KHUfIDggQ6AEILzAB\#v=onepage\&q=pengertian rpp\&f=false

Tirtoni, F. (2018). Pembelajaran terpadu di sekolah dasar. Sidoarjo: UMSIDA Press.

Wafiqni, N., \& Nurani, S. (2018). Model Pembelajaran Tematik Berbasis Kearifan Lokal. AL-BIDAYAH: Jurnal Pendidikan Dasar Islam, 10(2), 255-270.

Wahyuni, H. T., Setyosari, P., \& Kuswandi, D. (2016). Implementasi pembelajaran tematik kelas 1 SD. Edcomtech, 1(2), 129-136.

Wardhani, R. M. (2010). Peningkatan pendapatan masyarakat melalui diversifikasi produk olahan ikan (Abon tuna, dendeng lemuru, krupuk rambak tuna). Agritek, 11(2), 54-64.

Warman, D. (2019). Implementasi Pembelajaran Tematik Oleh Guru Kelas Pada Sekolah Dasar DiKecamatan Lembah Segar Kota Sawahlunto. Al-Fikrah: Jurnal Manajemen Pendidikan, 6(2), 185. https://doi.org/10.31958/jaf.v6i2.1394

Widowati, A. I., Utaminingsih, A., \& Wahjuningsih, S. B. (2018). Juicer sebagai upaya peningkatan kualitas produk jamu gendong. In Prosiding Seminar Pengabdian Kepada Masyarakat (SENADIMAS) (pp. 398-402). Surakarta: Universitas Slamet Riyadi.

Wijayanti, D., Kurniawan, V. R. B., \& Susanto, D. (2019). Perancangan kemasan ramah lingkungan berbahan corugated dan penerapan sistem pemasaran daring pada produk jamu tradisional Kiringan. Abdimas Dewantara, 2(1), 45-52.

Yayuk, E., Kuncahyono, K., \& Restian, A. (2017). Pendampingan penyusunan media pembelajaran digibook (Buku digital) di SDN Girimoyo 2 Kabupaten Malang. Publikasi Pendidikan, 7(3), 134-139. https://doi.org/10.26858/publikan.v7i3.3513

Yuniasih, N., Ladamay, I., \& Wahyuningtyas, D. T. (2014). Analisis pembelajaran tematik pada kurikulum $2013 \mathrm{di}$ SDN Tanjungrejo 1 Malang. Mimbar Sekolah Dasar, 1(2), 148-152. https://doi.org/10.17509/mimbar-sd.v1i2.876

Zendrato, J. (2016). Tingkat penerapan rencana pelaksanaan pembelajaran dalam pelaksanaan pembelajaran di kelas: Suatu studi kasus di SMA Dian Harapan Jakarta. Scholaria, 6(2), 58-73.

Zuriah, N., Sunaryo, H., \& Yusuf, N. (2016). IbM guru dalam pengembangan bahan ajar kreatif inovatif berbasis potensi lokal. Dedikasi, 13(1), 40. Retrieved from 1693-3214.. 